\begin{tabular}{|c|c|}
\hline \multirow{3}{*}{ 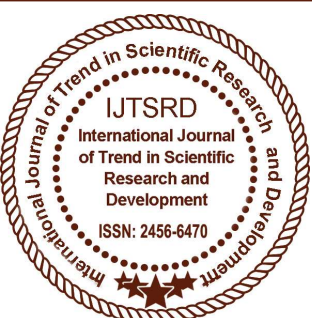 } & $\begin{array}{l}\text { International Journal of Trend in Scientific } \\
\text { Research and Development (IJTSRD) }\end{array}$ \\
\hline & International Open Access Journal \\
\hline & ISSN No: 2456 - 6470 | www.ijtsrd.com | Volume - 2 | Issue -4 \\
\hline
\end{tabular}

\title{
The FTIR Spectra of Raw Magnesite and Sintered Magnesite
}

\author{
D. Gopinath ${ }^{1}$, S. Gunasekaran ${ }^{2}$ \\ ${ }^{1}$ P. G. Scholar, ${ }^{2}$ Professor
}

St. Peter's Institute of Higher Education and Research, St. Peter's University, Avadi, Chennai, India

\begin{abstract}
Magnesite is a magnesium carbonate mineral because of its thermal stability and inertness. All the three grades of magnesite both in raw and sintered forms have vast applications. The FTIR spectra of raw magnesite and sintered magnesite samples have been recorded in the mid - infrared region of 4000-450 cm1. In general, vibrational spectroscopy detections can qualitatively and quantitatively distinguish the spectral assignment of specific bands between corresponding bonds and functional groups, as also the observation of spectral profiles can be used to define and differentiate the magnesite The present work is aimed to make an investigation magnesite
\end{abstract}

Keywords: Magnesite , FTIR

\section{INTRODUCTION}

Magnesium is one of most widely distributed elements in the earth crust of which it constitute nearly 2.7 percent and so occupies the sixth place on list (1) magnesium carbonate occurs in nature as magnesite and in association with calcium carbonate as dolomite. The majorly of magnesium oxide produced today is obtained from the processing of naturally occurring minerals such as magnesite (magnesium carbonate) (2). Large Mineral deposits of magnesia are in Austria, Brazil, Canada, China, Common wealth of Independent States, former Czechoslovakia, Greece, Turkey, North Korea, former Yugoslavia and the US. The commercial production of magnesia in India was started during the World War I, when imports of magnesium chloride was ceased and in indigenous resources must be developed to meet the needs of industry (4). The bitterns from marine salt works provided a convenient source material for magnesium chloride and the pioneer magnesia works limited Kraalhead, started production in 1916.

The Chemical name of magnesite is magnesium carbonate $\left(\mathrm{MgCO}_{3}\right)$ (i.e) Magnesite is a carbonate of magnesium. When pure, it contains $52.4 \%$ carbon di -oxide $\left(\mathrm{CO}_{2}\right)$ and $47.6 \%$ magnesium oxide $(\mathrm{MgO})(3)$. The magnesium and calcium bearing carbonates represent an important mineral group which is mined extensively. It is usually white, but it may be light to dark brown if iron bearing. Magnesite is an important industrial mineral. Various types of magnesite are produced by different thermal treatments and it is used in the production of calcined, dead- burned . Magnesite is converted to calcined magnesite when it heated between $700^{\circ} \mathrm{C}$ and $1000^{\circ} \mathrm{C}$ temperatures. Calcined magnesite is used in the manufacture of paints, paper, plastic, rubber, oil, pharmaceutical, fertilizer, animal feed, building materials and as a fire retardant. If calcined Magnesite is heated to $1500 \mathrm{C}$ to $1800 \mathrm{C}$, it will convert to dead- burned magnesite which is known as sintered magnesite and it is used predominantly for refractory bricks are widely used in many industrial sectors e.g. pharmaceutical and cosmetic industries, paint formulations and bulk applications including concrete and magnesia $(\mathrm{MgO})$ production. There have been a considerable number of studies suggesting that magnesite should be considered when evaluating the role of carbon in the earth's mantle. Magnesite is indeed a very good candidate for hosting oxidized carbon in the mantle, since experiments or calculations indicate that magnesite is, among all carbonates the most stable at 
high pressure and high temperature (6-11). Numerous experiments have been dedicated to determine the compression properties of magnesite, as these govern to some extent to its stability versus the composition into a mixture of oxides $\mathrm{MgO}$ and $\mathrm{CO}_{2}$. Recently the high-pressure behaviour of magnesite has been studied with angle dispersive X-ray diffraction by Fiquet et al and Reynard et al (12-15). Ross et all carried out even the structural refinement of megnesite at high pressure in 1997(16). Though many research works were carried out in magnesite at high pressure not much work was reported at high temperature. Here an attempt is made to study the behaviour of the ceramic $(\mathrm{MgO})$ at different temperatures, using infra red.

\section{Experimental and Methods:}

\section{FT- IR Spectral Analysis}

Natural samples of Raw Magnesite, LBM, HBM and different grades of DBM have been procured from TANMAG (Tamil Nadu Magnesite Limited), Salem, India. The FTIR spectra were recorded in the range 4000-400 $\mathrm{cm}^{-1}$ using Bruker IFS 66V FTIR spectrophotometer at SAIF, IIT, Chennai, India. Since the samples were not soluble in solvent and also the preparation of the film was very difficult, the IR spectra were recorded by the use of $\mathrm{KBr}$ pellet method. .

\section{Result and discussion}

Since the samples were not soluble in solvent and also the preparation of the film was very difficult, the IR spectra were recorded by the use of $\mathrm{KBr}$ pellet method. The FTIR spectra ofthe raw magnesite and the sintered magnesite samples are presented in Figs. 1 Different grades of DBM Spectra are presented in Figs..2 Recently the IR spectra have been utilized as an analytical tool by chemists and mineralogists. Many researchers collected the characteristic IR spectra of minerals and rocks for identification of known minerals and mixtures (20-24). IR technique was also applied to characterise the water and hudroxyl ions in the basic magnesium carbonate minerals by White(25). The thermal behaviour of calcite, kalonite and dolomite in ceramics were reported recently (26-28). The analysis of magnesite samples under the spectral invesitgation show interesting relationship with its machencial and electrical properties. The infrared spectrum or raw magnesite shows a very strong broad band at 1446 $\mathrm{cm}^{-1}$ due to the asymmetric $\mathrm{C}-\mathrm{O}$ stretching vibrations and it is in good agreement with the literature value (29). This band is identified by laitha et al (30) at $1450 \mathrm{~cm}^{-1}$ in apatites sample to confirm the presence of $\mathrm{CO}_{3}$ ion. As the sintering process takes place, this band slightly shifts to $1455 \mathrm{~cm}^{-1}$ with less absorbance. In DBM it completely disappears to show the absence of $\mathrm{CO}_{3}$ ion.

Another intense band at $856 \mathrm{~cm}^{-1}$ is characteristic of the $\mathrm{CO}_{3}$ asymmetric deformation as expected. This band appears with less intensity in LBM and disappears in both DBM. Similarly the weak bands at $1080 \mathrm{~cm}^{-1}$ and $680 \mathrm{~cm}^{-1}$ may be due to the $\mathrm{C}-\mathrm{O}$ symmetric and $\mathrm{CO}_{3}$ symmetric deformation vibration. Following the frequency assisgnment done by Nakamoto (29), the bands at $1446 \mathrm{~cm}^{-1}, 856 \mathrm{~cm}^{-1}$, $1080 \mathrm{~cm}^{-1}$ and $680 \mathrm{~cm}^{-1}$ are confirmed as fundamental modes of $\mathrm{CO}_{3}$ ion present $\mathrm{MgCO}_{3}$. These four bands that are due to the $\mathrm{CO}_{3}$ ion present in the raw magnesite $\left(\mathrm{MgCO}_{3}\right)$ sample disapper one by one in sintered magnesite sample to prove that the $\mathrm{CO}_{2}$ gas is explelled completely in the process of calcination at high temperature $\left(1750^{\circ} \mathrm{C}\right)$. The frequency interpretation is tabulated for raw in table 1 and sintered magnesites in Table.2. The values within the brecket gives the corresponding absorbance. The strong band near $887 \mathrm{~cm}_{-1}$ is due to the $\mathrm{Mg}-\mathrm{O}$ stretching vibration (29) and this is active in all grads of DBM. The observed fundamentals along with their assignments for different grades of DBM are presented in Table 3.3. Values of the absorbance of the characteristic bands corresponding to the components present are given within the parenthesis in the table. The spectra of different grades of DBM give rise to more or less same infrared characteristic bands since there is a very small variation in the percentage of components present in it. Comparing the percentage of $\mathrm{MgO}$ with other components of DBM it is very high and varies between $72 \%$ and $89 \%$ and thus leads to a variation of absorbance in the range $0.33 \%$ to $0.70 \%$. The second major contribution in $\mathrm{DBM}$ is due to $\mathrm{SiO}_{2}$ and shows absorbance up to $0.59 \%$.

The IR absorbance for $\mathrm{SiO}, \mathrm{Si}_{2} \mathrm{O}_{2}$ molecules are observed at $1224 \mathrm{~cm}^{-1}$ (SiO), $805 \mathrm{~cm}^{-1}, 766 \mathrm{~cm}^{-1}$ $\left(\mathrm{Si}_{2} \mathrm{O}_{2}\right), 973 \mathrm{~cm}^{-1}, 632 \mathrm{~cm}^{-1}, 312 \mathrm{~cm}^{-1}\left(\mathrm{Si}_{3} \mathrm{O}_{2}\right)$ by Ogden and Anderson (31). The peaks around $839 \mathrm{~cm}^{-}$ $1,987 \mathrm{~cm}^{-1}$ and $471 \mathrm{~cm}^{-1}$ are invariably present in all the grades of DBM, caused by a symmetrical stretching $(32,33)$, asymmetric stretching $(34,35)$ and bending vibrations $(36,37)$ of $\mathrm{Si}-\mathrm{O}$ group confirms its 
International Journal of Trend in Scientific Research and Development (IJTSRD) ISSN: 2456-6470

presence.Yousuf (38) ascribes the stretching vibrations of AI-O around $1000 \mathrm{~cm}^{-1}$ and the same is identified at $987 \mathrm{~cm}^{-1}$ in DBM grade samples and gives more or less the same value of absorbance. The stretching vibrations of Ca-O occur normally at 650 $\mathrm{cm}^{-1}$ (39) and here it is observed around $614 \mathrm{~cm}^{-1}$. The absorbance of this peak is very small compared to the other impurities like $\mathrm{AI}_{2} \mathrm{O}_{3}$ value . The strong band near $887 \mathrm{~cm}_{-1}$ is due to the $\mathrm{Mg}-\mathrm{O}$ stretching vibration (29) and this is active in all grads of DBM. The observed fundamentals along with their assignments for different grades of DBM are presented in Table 3.2

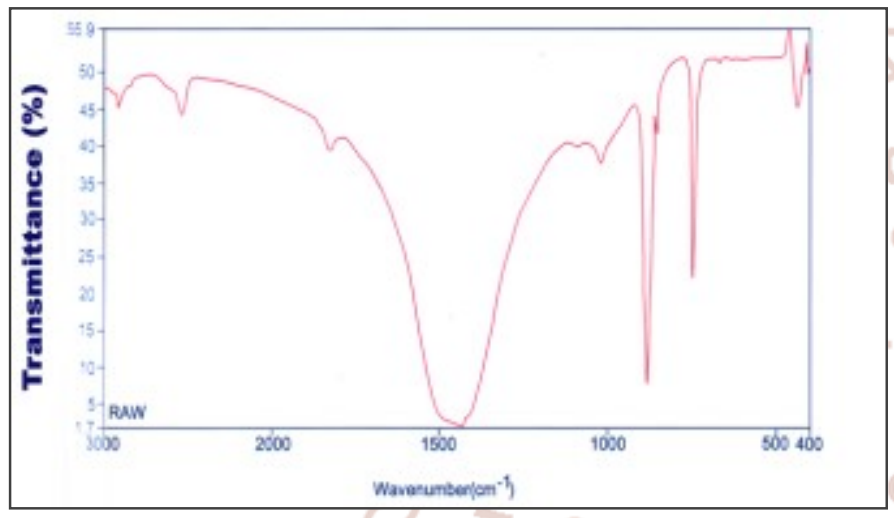

Fig 1 FTIR raw magnesite

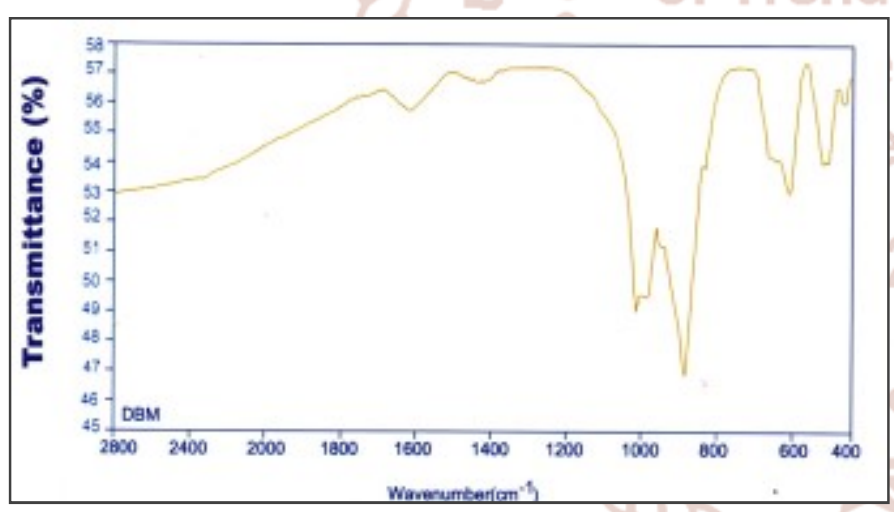

Fig 2 FTIR DBM magnesit
Table 1 FTIR spectral analysis on raw magnesite different Grades

\begin{tabular}{|c|c|c|c|}
\hline $\begin{array}{c}\text { Band } \\
\text { assignments }\end{array}$ & $\begin{array}{c}\text { Grade } 1 \\
\text { Wave } \\
\text { number } \\
\text { cm- }^{-}\end{array}$ & $\begin{array}{c}\text { Grade } 1 \\
\text { Wave } \\
\text { number } \\
\text { cm- }^{1}\end{array}$ & $\begin{array}{c}\text { Grade } 1 \\
\text { Wave } \\
\text { number } \\
\text { cm- }^{-1}\end{array}$ \\
\hline Mg-O & 885 & 885 & 885 \\
\hline $\begin{array}{c}\mathrm{SiO}_{2} \\
\text { Asymmetric } \\
\text { Stg }\end{array}$ & 1020 & 1020 & 1020 \\
\hline $\begin{array}{c}\text { Asymmetric . } \\
\text { CO } \\
\text { stg }\end{array}$ & 1446 & 1446 & 1446 \\
\hline $\begin{array}{c}\text { Asymmetric } \\
\text { CO } \\
\text { stg }\end{array}$ & 1080 & 1080 & 1080 \\
\hline $\begin{array}{c}\text { Asymmetric } \\
\mathrm{CO}_{3} \\
\text { def } \\
\end{array}$ & 856 & 856 & 856 \\
\hline $\begin{array}{c}\text { symmetric } \\
\mathrm{CO}_{3} \\
\text { def }\end{array}$ & 680 & 680 & 680 \\
\hline
\end{tabular}

Table 2 FTIR spectral analysis on Sintering magnesite different Grade

\begin{tabular}{|c|c|c|c|}
\hline $\begin{array}{c}\text { Band } \\
\text { assignments }\end{array}$ & $\begin{array}{c}\text { Wave } \\
\text { number } \\
\mathbf{c m}^{\mathbf{1}}\end{array}$ & $\begin{array}{c}\text { Wave } \\
\text { number } \\
\mathbf{c m}^{\mathbf{1}}\end{array}$ & $\begin{array}{c}\text { Wave } \\
\text { number } \\
\mathbf{c m}^{-}{ }^{-}\end{array}$ \\
\hline $\begin{array}{c}\text { Mg-O } \\
\text { SiO }\end{array}$ & 887 & 886 & 887 \\
\hline $\begin{array}{c}\text { Asymmetric } \\
\text { Stg }\end{array}$ & 1017 & 1018 & 1017 \\
\hline $\begin{array}{c}\text { Asymmetric } \\
\mathbf{C O} \\
\text { stg }\end{array}$ & - & - & - \\
\hline $\begin{array}{c}\text { Asymmetric } \\
\mathbf{C O} \\
\text { stg }\end{array}$ & - & - & - \\
\hline $\begin{array}{c}\text { Asymmetric } \\
\mathbf{C O} \\
\text { def }\end{array}$ & - & - & \\
\hline $\begin{array}{c}\text { symmetric } \\
\mathbf{C O} \\
\text { def }\end{array}$ & & & \\
\hline
\end{tabular}




\section{Conclusions}

The FTIR measurement is used to analyze the samples of magnesite .. The FTIR technique is used to identify the characteristic bands of Silicate, aluminium, iron, present in the mineral, and a spectral analysis is also carried by FTIR. It is observed that the magnesite is more stable and has high mechanical strength, because of the presence of silica. The spectroscopic instrumentation techniques are used to conclude out of the three grade,. They are in good agreement with the FTIR techniques and dielectric measurement results.

\section{Acknowledgements}

The authors are thankful to TANMAG (Tamil Nadu Magnesite Limited), Salem, India. for providing the samples and for their supported throughout the research. One of the authors Mr.Gopinath is thankful to St. Peteres University for providing the University Research fellowship to Carried out my Ph.D programme.

\section{References}

1) Robert $\mathrm{M}$ Silver stein, Spectrometric identification of organic compounds, John Wiley and Sons, New York (1981).

2) Conley R T. Infrared spectroscopy, $2^{\text {nd }}$ Edition, Allyn and Bacon, Boston (1972)/

3) Nakanishi, Koji, Soloman P H, Infrared absorbance spectroscopy-Practical, $2^{\text {nd }}$ Edition, Holden-Day, San Francisco (1977).

4) Colthup $\mathrm{N}$ D, Daly L H and Wiberley S.E, Introduction to infrared and spectroscopy, $2^{\text {nd }}$ Edition, Academic press, New York and London (1975).

5) Jallo H N A and Jalhovn M G, Spectrochim Acta, 31A,265 (1975).

6) Dabrouski J, Spectrochim Acta, 19, 475 (1963).

7) Erskine R L and Waight E S, J.Chem. Soc., 3425 (1960).

8) Jakohsen R J and Bentley F F, App. Spectrosc, 18, 88 (1964).

9) Verdonck L et al, Spectrochim Acta, 30A, 813 (1973).

10) Higuchi $S$ et al, Spectrochim Acta, 30A 463 (1974).
11) Aruldhas G, Molecular structure and Spectroscopy, Prentice Hall of India (2001).

12) Smith A L, Applied infrared spectroscopy, Prentice Hall of India (2001).

13) Silverstein R.M. Bassler G C and Morril T.C, Spectrometric identification of organic compounds, John Wiley and Sons, New York (1991).

14) Albert N.L.KeiserW E and Sizymansky H.A, I RTheory and Practice of Infrared spectroscopy, $2^{\text {nd }}$ Edition, Plenum, New York (1967).

15) Bingel W A, Theory of Molecular Spectra, John Wiley and Sons, London (1969).

16) Miller R G J and Stace D C, Edision, Laboratory methods in infrared spectroscopy $2^{\text {nd }}$ Edition, Hayden and Sons, London (1972).

17) Krishnan K, Hill S L and Gelpand L S, Proc.Soc.photo-opt. Instrum 553,338 (1985).

18) Krishnan K Proc.Soc.photo-opt. Instrum 665,252 (1986).

19) Krishnan Kand Kuehl D T, ASTM, Spec.Tech. Publ., 850, 325 (1984).

20) Adam S F, Microwave theory and application, Prentic-Hall, USA (1969).

21) Chatterjee $R$, Elements of Microwave engineering, affiliated to East -West Press, Pvt.Ltd, New Delhi (1984).

22) Chodoron $M$ and Sussikind C, Fundamentals of Microwave Electronic,McGraw Hill, New York(1964).

23) Liao $\mathrm{S} Y$, Microwave devices and circuits, Prentice Hall, Eaglewood Cliff, N.J.USA (1991).

24) D. A. Skoog, F. J. Holler, T. A. Nieman, "Principles of Instrumental Analysis"Saunders College Publishing, Philadelphia, USA (1998)

25) L. V. Azaroff, M. J. Buerger, "The Power Method in X-ray Crystallography", McGraw-Hill, New York, USA (1958)

26) B. D. Cullity, "Elements of X- Ray diffraction", Addison - Wesley, Boston, USA(1956)

27) H. P. Klug, L. E. Alexander, "X-ray Diffraction Procedures", 2nd ed., Wiley, NewYork, USA (1974) 
International Journal of Trend in Scientific Research and Development (IJTSRD) ISSN: 2456-6470

28) M. M. Woolfson, "An introduction to x-ray Crystallography", Cambridge University Press, Cambridge, USA (1997)

29) B. E. Warren, X - Ray Diffraction, Dover, New York, USA (1969)

30) C. Suryanarayana, M. Grant Norton, "X - Ray Diffraction : A Practical Approach”,Plenum press, New York, USA (1998)

31) P. P. Ewald, "Fifity years of X - Ray Diffraction", IUCR XVIII Congress, Glasgow, Scotland (1999)

32) T. Irusan, D. Arivuoli, P. Ramasamy, Cryst Res Technol 25 (1990) K104

33) J. Drenth, "Principles of Protein Crystallography", Springer, New York, USA (2007)

34) R. S. Rowlett, "Protein X - Ray Crystallography Methods", Colgate University, New York, USA (2005)

35) R. W. G. Wyckoff, R. B. Corey, J BiolChem 116 (1936) 51

36) C. R. Brundle, A. Charles, Jr. Evans, S. Wilson, "Encyclopedia of materials characterization", Butterworth- Heinemann Publications, Elsevier, Greenwich, UK (1992)

37) D. B. Williams, C. B. Carter, "Transmission Electron Microcopy: A Text book of Material Science", Springer, New York, USA (2009)

38) J. C. Delman: Low Temperature Formation of Dolamite and Magnesite. Compact Disc Publications, Eindhoven, (2005) 2.33.

39) K. Wright, R.T. Cygan, B. Slater: Structure of the (1014) Surfaces of Calcite, Dolomite and Magnesite under Wet and Dry Conditions. Phys. Chem. Chem. Phys. 3 (2001)839 - 844.

40) E. Tuncer, N. Bowler, I.J. Youngs, K.P. Lymer: Investigating Low Frequency Dielectric Properties of a Composite Using the Distributing of Relaxation Times Technique. Philosophical Magazine Vol. 86 No 16 (2006) 2359 - 2369.
41) J. Li, K. Cho, N. Wu, A. Ignatiev: Correlation between Dielectric Properties and Sintering Temperatures of Polycrystalline $\mathrm{CaCu} 3 \mathrm{Ti} 4$ O12.IEEE Transactions on Dielectrics and Electrical Insulation Vol. 11 No. 3 (2004) 534 541.

42) E. Barsoukov, J. R. Macdonald: Impedance Spectroscopy Theory, Experiment, and Applications. A John Wiley \& Sons, Inc., (2005) $1-129$.

43) W. D. Kingery, H. K. Bowen, D.R. Uhlmann: Introduction to Ceramics. Willey Interscience Pub. (1975) 913 - 974.

44) Grinblat A., Bern F., Barzola - Quiquia J. , Tirado M., Comedi D., Esquinazi P. 2014, Electrical properties and luminescence of single $\mathrm{ZnO} / \mathrm{MgO}$ core/shell nanowires, Appl. Phys. Lett.,104, 103113.

45) IN-CHYUAN HO, UHUAN XU, JOHN D. MACKENZIE, 1997, Electrical and Optical Properties of $\mathrm{MgO}$ Thin Film Prepared by Sol-Gel Technique, Journal of Sol-Gel Science and Technology, 9, 295.

46) Yong Shin D., Nam Kim K., 2009, Electrical and optical properties of $\mathrm{MgO}$ films deposited on soda lime glass by a sol-gel process using magnesium acetate, Journal of Ceramic Processing Research, 10,536 .

47) Bondoux C., Prené P., Belleville P., Guillet F., Lambert S., Minot B., Jérisian R., 2004, Sol - Gel $\mathrm{MgO}$ Thin Films for Insulation $\mathrm{SiC}$, Materials Science in Semiconductor Processing, 7, 249.

48) Miranda E., O'Connor E., Hughes G., Casey P., Cherkaoui K., Monaghan S., Long R., O'Connell D., Hurley P. K., 2009, Soft breakdown in $\mathrm{MgO}$ dielectric layers, Reliability Physics Symposium, 26-30 April (2009), Montreal QC, 688-691.

49) Moses A., Jayachandran M., Sanjeeviraj C., 2010, Fabrication techniques and materials properties of dielectric $\mathrm{MgO}$ thin films, CIRP Journal of Manufacturing Science and Technology, 2, 92. 